Images in...

\title{
Nasal tooth: an unusual cause of nasal obstruction and sinusitis
}

Rupert George Ricks, Ahmed Shaaban

ENT Department, Southmead Hospital, North Bristol NHS Trust, Bristol, UK

Correspondence to Mr Rupert George Ricks, rupert.ricks@nbt.nhs.uk

\section{DESCRIPTION}

A 34-year-old lady presented with nasal obstruction and sinusitis. She had been having such symptoms for many years despite best medical therapy for several months. Nasal examination revealed a rhinolith in the floor of the nasal cavity with significant rhinitis and mucopus in the middle meatus. After initial examinations were made the pathology of the rhinolith was not clear. CT scans revealed the rhinolith to be an ectopic tooth arising from the incisive foramen (figures 1 and 2). Endoscopic removal and FESS resulted in full resolution of the symptoms (figure 3). Ectopic teeth are a rare finding; less than 30 cases have been reported in the international literature. ${ }^{1-3}$ They can arise throughout the mid face including the palate, mandibular condyle, coronoid process, orbit, maxillary antrum and nasal cavity. ${ }^{4}$ Symptoms of nasal teeth include epistaxis, nasal obstruction, rhinorrhoea (often foul smelling), headache, facial pain and sinusitis. ${ }^{5}$ Nasal teeth are unlikely to be diagnosed following examination alone as they are often covered in granulation tissue and infected debris. The diagnosis however, is easy to make with CT scans and endoscopic removal is usually a straight forward procedure. Causes include cleft palate, mid-face trauma, Gardner's syndrome and cleido-cranial dysostosis, however

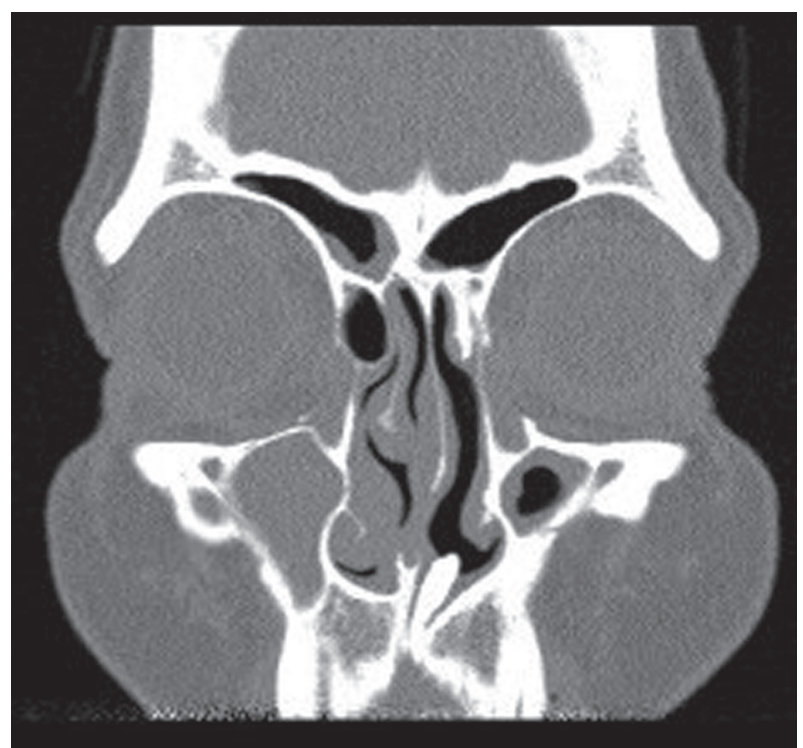

Figure 1 Coronal CT demonstrating ectopic tooth in left nasal cavity. the majority of cases have no obvious cause noted. ${ }^{6-8}$ These images illustrate a rare and interesting cause of nasal obstruction and sinusitis that was refractory to best

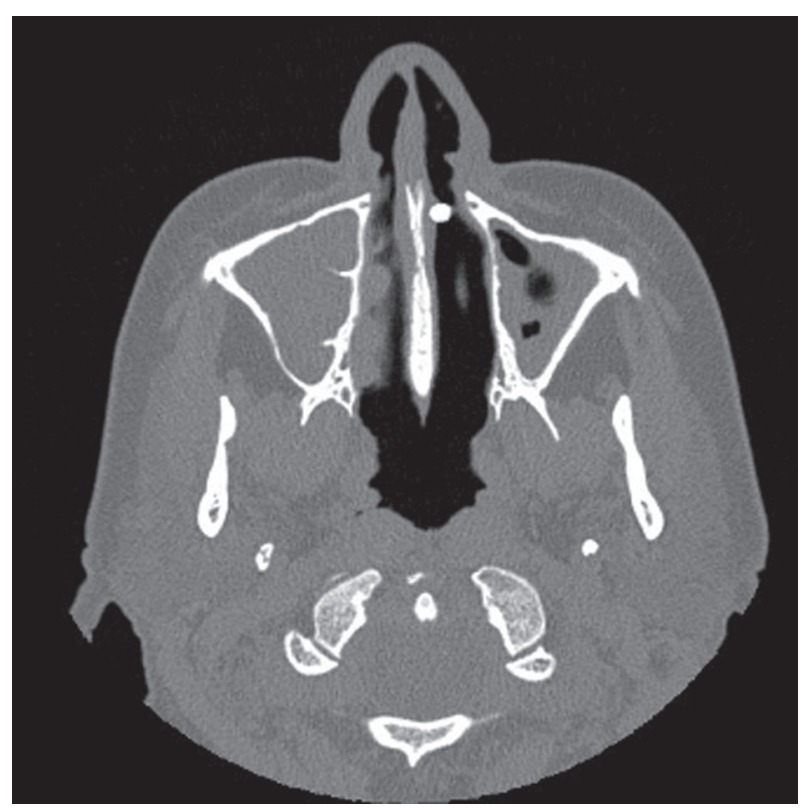

Figure 2 Axial CT demonstrating tooth in left nasal cavity.

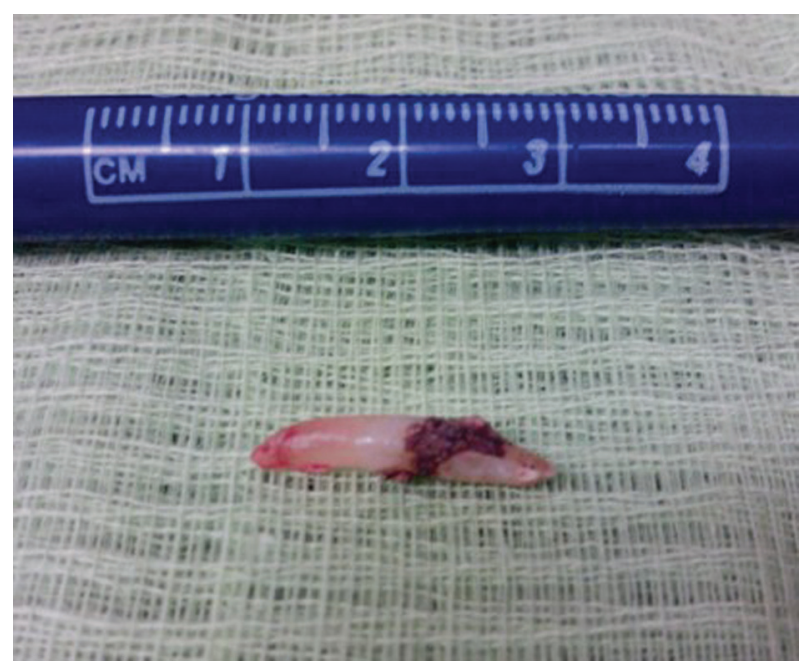

Figure 3 Nasal tooth after endoscopic removal. 


\section{BMJ Case Reports}

medical therapy. As with all common illnesses that do not respond to conventional treatment a logical approach to management and specialist advice are invaluable. With the appropriate diagnosis, definitive treatment can be started and the patient cured.

Competing interests None.

Patient consent Not obtained.

\section{REFERENCES}

1. Kirmeier R, Truschnegg A, Payer $M$, et al. The supernumerary nasal tooth. Int J Oral Maxillofac Surg 2009;38:1219-22.
2. Lin IH, Hwang CF, Su CY, et al. Intranasal tooth: report of three cases. Chang Gung Med J 2004;27:385-9.

3. Nisa L, Giger R. Images in clinical medicine. Ectopic tooth in the maxillary sinus. N Engl J Med 2011;365:1232.

4. Lee JH. A nasal tooth associated with septal perforation: A rare occurrence. Eur Arch Otorhinolaryngol 2006;263:1055-6.

5. Chen A, Huang JK, Cheng SJ, et al. Nasal teeth: report of three cases. AJNR Am J Neuroradiol 2002;23:671-3.

6. Thawley SE, LaFerriere KA. Supernumerary nasal tooth. Laryngoscope 1977;87:1770-3.

7. Moreano EH, Zich DK, Goree JC, et al. Nasal tooth. Am J Otolaryngol 1998:19:124-6.

8. Lee FP. Endoscopic extraction of an intranasal tooth: a review of 13 Cases. Laryngoscope 2001;111:1027-31.

This pdf has been created automatically from the final edited text and images.

Copyright 2012 BMJ Publishing Group. All rights reserved. For permission to reuse any of this content visit

http://group.bmj.com/group/rights-licensing/permissions.

BMJ Case Report Fellows may re-use this article for personal use and teaching without any further permission.

Please cite this article as follows (you will need to access the article online to obtain the date of publication).

Ricks RG, Shaaban A. Nasal tooth: an unusual cause of nasal obstruction and sinusitis. BMJ Case Reports 2012;10.1136/bcr.09.2011.4767, Published XXX

Become a Fellow of BMJ Case Reports today and you can:

- Submit as many cases as you like

- Enjoy fast sympathetic peer review and rapid publication of accepted articles

- Access all the published articles

- Re-use any of the published material for personal use and teaching without further permission

For information on Institutional Fellowships contact consortiasales@bmjgroup.com

Visit casereports.bmj.com for more articles like this and to become a Fellow

Keep up to date with all published cases by signing up for an alert (all we need is your email address) http://casereports.bmj.com/cgi/alerts/etoc 